\title{
Is Group Ontology Morally Distracting? A Natural Law Approach to Corporate Religious Liberty
}

\author{
Edward A. David*
}

\begin{abstract}
In recent years, a variety of corporate litigants, from houses of worship to for-profit enterprises, have brought religious liberty suits to the US Supreme Court. Interestingly, the metaphysical status of such litigants has been subject to intense debate by judges and commentators alike. Are these litigants corporate moral persons or mere aggregates of individuals? How, if at all, does their metaphysical status affect our assignment of corporate rights to religious freedom? While many have entertained such questions, others reject them as morally distracting. This article challenges that latter position. Drawing upon the natural law tradition, I argue that group ontology can be used in the assignment of corporate rights in a morally illuminating way. I point out the tradition's distinctive ontology, which views groups primarily as social actions, subject to moral evaluation. I then discuss how this conception moves attention away from polarizing rights-based discourse towards measured consideration of what is morally right. Finally, I show how this ontology helps practical reasoning to discover a variety of (non-rights-based) reasons and means to protect religious freedoms as well as other moral stakes. Far from causing moral distraction, a natural law group ontology facilitates careful moral deliberation.
\end{abstract}

\section{INTRODUCTION}

When one hears of religious liberty disputes involving, say, a church's ability to discriminate when hiring ministers ${ }^{1}$ or a for-profit firm's exemption from mandatory contraceptive coverage, ${ }^{2}$ the term 'group ontology' may not be the first thing to come to mind. But arguments claiming that 'a group's moral personality is sufficient

* Edward A. David, Faculty of Theology and Religion, University of Oxford, Oxford, UK. E-mail: edward. david@nyu.edu. I indebted to Dominic Burbidge, Mehmet Ciftci, Mark Lee, and Paul Yowell for thoughtprovoking comments on early drafts of this article. I am also grateful to Maria Cahill and Nigel Biggar for opportunities to present this article at the School of Law, University College Cork (with travel support from the Acton Institute) and Christ Church College, University of Oxford. Finally, I thank the reviewers of the Oxford Journal of Law and Religion for their careful and generous critique. Any opinions expressed and errors made are solely my own.

1 Hosanna-Tabor Evangelical Lutheran Church and School v EEOC (2012) 132 SCt 694 (a church's school teacher was considered a 'minister' for purposes of the ministerial exception).

2 Burwell v Hobby Lobby Inc (2014) 134 SCt 2751 [the federal government's contraceptive mandate violated the religious liberty rights of objecting closely held corporations, as protected under the federal Religious Freedom Restoration Act (RFRA)]. 
ground for extending legal rights to it ${ }^{3}$ or that 'a corporation's artificial status makes it incapable of exercising religion and thus unable to seek religious exemptions ${ }^{4}{ }^{2}$ reveal a deep conviction that understanding what a group (ontologically) is is necessary for crafting just legal protections.

Nevertheless, the use of group ontology in the assignment of corporate rights to religious freedom has come increasingly under fire in recent years. Prominent political liberals, including Cécile Laborde, Richard Schragger, and Micah Schawrtzman, claim that its attention to the metaphysical (the 'what is' of groups) distracts from the moral stakes involved and, thus, does nothing useful for corporate rights analysis. ${ }^{5}$ At best, they claim, group ontology is morally indeterminate with respect to rights ascription; at worst, it results in morally inappropriate and even dangerous policy proposals. Better then to avoid the question 'What is a group?' and to begin instead with the morally focused query: 'How would giving this group legal rights and duties affect our social relations? ${ }^{6}$

Notwithstanding the certain merits of the above position, my aim in this article is to argue that group ontology can be used in the assignment of corporate rights (to religious freedom) in a morally illuminating, and not distracting, way.

Drawing upon the natural law tradition and its distinctive group ontology, I put forward two arguments in defence of a group ontological approach to corporate religious liberty. First, I argue that group ontology and morality are distinct yet interdependent fields of knowledge and, thus, are both necessary for a morally adequate corporate rights ascription. Afterward, I argue that a proper group ontology views groups primarily as social actions and thereby emphasizes morally right action, replacing inadequate rights-based moral analyses. I develop these (largely theoretical) arguments in Sections 2 and 3. From there, I illustrate in Section 4 what a procedure of corporate rights ascription could look like in actual practice and when informed by the group ontological and moral insights of the natural law tradition. In that section and throughout this article, I focus upon the contemporary American context. But the points raised should be seen for their universal application.

With regard to the specific group ontology, I have in mind, I draw extensively upon the model offered by Saint Thomas Aquinas, especially as developed by the legal philosopher John Finnis. Regrettably, this ontology and its natural law context have not been sufficiently deployed in today's highly polarized debates over corporate religious liberty. But, as we will see, it is an ontology that-through its emphases upon right action and shared moral deliberation-offers numerous theoretical and practical benefits for those diverse parties involved in corporate religious liberty disputes.

3 For arguments along these lines, see John Garvey, What Are Freedoms For? (Harvard University Press 1996) 146-51; Roger Scruton, 'Corporate Persons: I - Roger Scruton' (1989) 63 Proceedings of the Aristotelian Society, Supplementary Volumes 239, 257-60.

4 For a similar argument, see Burwell (n 2) 2794 (Ginsburg, J, dissenting) ('the exercise of religion is characteristic of natural persons, not artificial legal entities').

5 Cécile Laborde, Liberalism's Religion (Harvard University Press 2017) 172-74; Richard Schragger and Micah Schwartzman, 'Some Realism about Corporate Rights' in Micah Schwartzman, Chad Flanders and Zöe Robinson (eds), The Rise of Corporate Religious Liberty (Oxford University Press 2016) 360-69.

6 Schragger and Schwartzman, ibid 360; quoted in Laborde, ibid 173. 
This article should therefore be seen as a three-fold contribution to the contemporary debate. It defends group ontology's use in the assignment of corporate rights. It makes known the natural law tradition's distinct group ontology and demonstrates its use for moral deliberation. And, along the way, it criticizes those approaches to corporate religious liberty, which, due to their poor group ontologies or normative commitments, fail to move forward the contemporary moral debate.

Without further delay, I turn to a first defence of group ontology's use in corporate rights ascription.

\section{GROUP ONTOLOGY AND MORALITY}

In the long history of corporate rights ascription, group ontology has generally been deployed, or at least conceived of, in two ways. One approach-what I refer to as the metaphysical method - involves understanding what a thing is and then determining the rights and duties that the thing should enjoy based upon its inherent nature. Associated with this method are Pope Innocent IV in the 13 th century, ${ }^{7}$ Frederic Maitland and Otto von Gierke in the late 19th century, ${ }^{8}$ and in recent decades, Roger Scruton and John Garvey. ${ }^{9}$ By contrast, the second approach-the empirical method - proceeds in an opposite manner: rights and duties do not follow from conclusions about essence; rather, they are first given to the thing (either actually or hypothetically), consequences are then analysed and the rights ascription is accepted or rejected. Associated with this method especially is John Dewey, ${ }^{10}$ who in the early 20th century is said to have 'put an end to such interminable disagreements about the nature of corporate entities' and their rights. ${ }^{11}$ For those who today follow Dewey's methodological insights, group ontology is more or less irrelevant, and even dangerous, for the assignment of corporate rights.

So which methodological tradition should we endorse? I suggest neither. In this section, I critique both methods by evaluating two current uses of group ontology (what I call group ontological paradigms) that are informed by them: a corporate personality paradigm associated with the former and a paradigm of voluntary association aligned with the latter. Afterward I offer an alternative account of group ontologyone found within the classical natural law tradition - that is able to facilitate the fundamental moral analysis required for an adequate ascription of corporate rights to religious liberty. The primary aim of this section is thus two-fold: it begins to make plain the methodological benefits associated with a natural law conception of groups, and it thereby defends the use of group ontology in corporate rights ascription.

7 See discussion in John Dewey, 'The Historic Background of Corporate Legal Personality' (1926) 35 Yale Law Journal 655, 665. The so-called progenitor of the fiction theory of the corporation, Pope Innocent IV is not so much a proponent of the metaphysical method, as he is (or is seen to be) someone who uses corporate theory to justify pre-determined moral positions. As discussed below, proponents of the empirical method eschew this approach.

8 ibid; Frederic W Maitland, 'Introduction' in Otto Gierke (ed), Political Theories of the Middle Ages (Cambridge University Press 1938) xl-xliii; Gierke (ed), ibid 68-73.

9 Scruton (n 3) 257-60; Garvey (n 3) 146-51.

10 Dewey (n 7).

11 Schragger and Schwartzman (n 5) 346. 


\section{A. Group Ontology as Morally Distracting}

Group ontology need not cause moral distraction, yet we see it often used in morally distracting ways. Take, for instance, the argument that organized groups have corporate moral personalities and, because of this, deserve legal solicitude. Schragger and Schwartzman break down this argument, as it is typically presented, into its component parts: it (i) establishes that groups themselves have rational agency, (ii) shows rational agency to support moral personality, (iii) uses moral personality to ground moral rights, and (iv) protects moral rights through corporate legal protections. ${ }^{12}$ The logic of this so-called 'standard argument' constitutes what we can call the corporate personality paradigm. This paradigm follows the metaphysical method's penchant for determining the essence of a thing, then assigning to it rights and duties. ${ }^{13}$ It is more specific than the metaphysical method generally stated, of course, in that it specifically maintains the presence of a sui generis group personality upon which moral and legal rights are based.

An example of this paradigm is Roger Scruton's corporate personality defence of corporations. In an exchange with John Finnis, Scruton argues that certain corporate persons (especially the church) possess a sui generis agency, enjoy moral personality, and, ultimately, are ends in themselves. ${ }^{14}$ They embed individuals within an 'ecology of rational agency', whereby individual persons are made aware of their heritage, including their moral obligations generated by past generations for the sake of present and future societies. ${ }^{15}$ But while corporate persons do indeed serve individuals in some instrumental way, they themselves (argues Scruton) are moral agents ('institutions ... which have personality ${ }^{16}$ ) deserving of their own legal protection. ${ }^{17}$

As alluded to above, the main difficulty with this line of reasoning pertains to moral analysis. In short, the paradigm it comprises obfuscates moral deliberation: it pays too much attention to one ethically salient fact (corporate moral personality) then proceeds too hastily to a legal conclusion. ${ }^{18}$ In its haste, the paradigm passes over other ethically salient factors, such as the moral rights of affected flesh-andblood individuals ('persons' in the primary, classical sense ${ }^{19}$ ).

Of course, one might say that corporate moral personality has more ethical weight than individuals' moral rights and that corporate personality ought therefore to direct our ethical deliberation. ${ }^{20}$ But this response does not settle our moral questions. In

12 ibid 438-353.

13 Dewey (n 7) 660.

14 Scruton (n 3) 257-60.

15 ibid 266.

16 ibid 252.

17 ibid 260. Relatedly, Scruton argues that corporate persons (ie non-instrumental institutions, which have moral personality) are best protected by the English law of trusts, which 'enable moral persons to create their own legal identity, and to claim the recognition which is due to them, while asking permission of no one besides their members'.

18 Schragger and Schwartzman (n 5) 348-60; Laborde (n 5) 173; John Finnis, 'Persons and Their Associations' in Intention and Identity: Collected Essays, vol 2 (Oxford University Press 2011) 98.

19 ST III, q 16, a 12, obj 2 and ad 3 ('a person is nothing else than an individual substance of rational nature,' and 'a person signifies something complete and self-subsisting in rational nature'). Here and henceforth, I reference the English Dominicans' translation of the Summa Theologiae, using book, question, and article enumeration. See Thomas Aquinas, Summa Theologiae (English Dominicans ed, Blackfriars 1964). Scruton (n 3) 257-60; Garvey (n 3) 146-51. 
fact, it raises more of them. Which groups, for example, have moral personalities worth protecting? And if two groups' moral personalities and rights are in conflict (the state versus a church, for instance), which personality and whose rights win? Furthermore, the corporate personality paradigm seems to overlook the fact that corporate rights involve 'power over others'. As Laborde states, 'Groups, far more than natural persons, have the capacity to dominate individuals, exercising power over their choices and undermining their autonomy. ${ }^{21}$ While we may disagree with Laborde concerning the place of individual autonomy as an ultimate moral value, her point concerning group domination (whether perpetrated by a state, church, or private firm) should at least be taken into serious consideration. Indeed, some may say that all of political history can be narrated in terms of the conflict between groups and of the various moral harms involved. ${ }^{22}$

In a separate line of defence, others may say that the corporate personality paradigm is morally acceptable because it is merely metaphorical or, as Ronald Dworkin puts it, involves a 'deep personification'. ${ }^{23}$ But even deployment as a metaphor does not salvage this paradigm. By focusing upon the rights of this or that metaphorical 'person' (or group), it continues to remove flesh-and-blood persons and the conditions conducive to their well-being from the focus of moral discourse. Moreover, deep personification risks obscuring who exactly is to be held to account in circumstances involving collective responsibility (say, of a nation's act of war) or the moral obligations of public officials (who ought to follow the same moral requirements as private citizens). ${ }^{24}$

In sum, corporate moral personality is no silver bullet for resolving our moral questions around corporate legal rights. Attention to it alone not only short circuits moral deliberation but it also poses significant risks pertaining to group domination, individual responsibility, and overall human well-being. A different paradigm and a different underlying method would be most welcome.

We turn then to an alternative, the voluntary association paradigm, which is made possible in part by the logic of the empirical method. Might this paradigm prove morally illuminating? Not entirely. Despite its certain merits, this paradigm tends towards and results from a narrow moral vision. Along the way, it ethically distracts.

To begin to evaluate this paradigm, it helps to see it too in its component parts: the paradigm (i) leaves aside metaphysical questions concerning what groups are, (ii) draws attention to the social or moral relations affected by rights ascription, (iii) holds individual autonomy or integrity as a fundamental and even overriding value, and (iv) gives the state final, but not arbitrary, authority in deciding moral or boundary disputes between individuals and their groups or between groups themselves. Following from these, the paradigm (v) grants state-sanctioned rights to

22 For example, see Francis Fukuyama, The Origins of Political Order: From Prehuman Times to the French Revolution (Profile Books 2011). For an older critique of group domination, done through imperial activity, see the 1902 text by JA Hobson, Imperialism: A Study (Routledge 2016).

23 Ronald Dworkin, Law's Empire (Hart Publishing 1998) 172.

24 ibid 172-75; John Finnis, 'Purposes, Public Acts, and Personification' in Intention and Identity (n 18) 8386. 
groups that are seen to promote right social relations, as identified by their respect for the autonomy or integrity of individual members.

As stated, this paradigm tracks closely recent articulations of freedom of association, especially those of Laborde and, separately, Schragger and Schwartzman. ${ }^{25}$ And in comparison to the corporate personality paradigm, there is much to admire in it. For one, its political liberal focus upon the individual helps avoid potential excesses in group power. ${ }^{26}$ Furthermore, its recognition of the state's arbitrating (yet not arbitrary ${ }^{27}$ ) role in boundary disputes speaks at minimum to the need of maintaining a political common good shared by diverse individuals and groups. ${ }^{28}$ Arguably, the corporate personality paradigm is unable to do either: that paradigm risks overemphasizing groups at the expense of individuals, and it offers no means to adjudicate between competing group rights. Indeed, as Laborde might say, it 'distract $[\mathrm{s}]$ attention from the underlying facts and interests that ought to guide our legal and moral assessment'. ${ }^{29}$

But, we must ask: does the paradigm of voluntary association not distract? Does it truly draw our attention to the full range of facts and interests at stake in corporate rights ascription? I do not think it does. And the reason for this pertains most to the paradigm's political liberal foundations. Consider the following.

In addition to an emphasis upon the individual and state sovereignty, certain influential strands of political liberal thought either (i) reject religion as incompatible with liberal values $^{30}$ or (ii) redefine religion so as to make it compatible with those values $^{31}$. Through either approach, the exercise of religion is most properly enjoyed within the four walls of voluntary and religiously homogenous communities. This organizational constraint circumscribes religion's problematic tendencies (on Leiter's understanding) or safely optimizes its integrity promoting effects (as Laborde argues) while safeguarding vulnerable third parties.

The paradigm of voluntary association stands upon these political liberal commitments. In doing so, it restricts corporate religious liberty rights to a narrow set of organizational types. Yet, we should hesitate to accept this restricted scope, just as we should question the paradigm's tendencies to devalue religion or to make religion into political liberalism's image and likeness. ${ }^{32}$ Indeed, religion can be otherwise and more

Laborde (n 5) 173-78; Richard Schragger and Micah Schwartzman, 'Against Religious Institutionalism' (2013) 99 Virginia Law Review 972.

26 Laborde (n 5) 174.

27 Laborde, ibid 168 ('a sovereign state has liberal legitimacy only if it pursues a recognizably liberal conception of justice, and does so democratically').

28 I have in mind Finnis's definition of the (political) common good: 'a set of conditions which enables the members of a community to attain for themselves reasonable objectives, or to realize reasonably for themselves the value(s), for the sake of which they have reason to collaborate with each other (positively and/ or negatively) in a community'. John Finnis, Natural Law \& Natural Rights (2nd edn, Oxford University Press 2011) 155. I discuss the common good again. See below in Section 4B(i).

29 Laborde (n 5) 172.

30 Brian Leiter, Why Tolerate Religion? (Princeton University Press 2014). Leiter begrudgingly tolerates 'religion qua religion', that is, religion as 'categorical' and insulated from 'ordinary standards of evidence' (34) (emphasis in original).

31 Laborde (n 5). For a historical survey of this approach, see J Judd Owen, Making Religion Safe for Democracy: Transformation from Hobbes to Tocqueville (Cambridge University Press 2015). 
convincingly conceived. Religion on a natural law account is much more substantive (contributing to human well-being) than either Leiter or Laborde wishes to admit. John Finnis, for instance, speaks of religion in three interrelated ways: first, as the human questing for the truth of reality and one's practical response to $\mathrm{it}^{33}$; second, as the recognition of a divine nature, understood as the proper and real object of that questing $^{34}$; and third, as the acknowledgement of possible revelations from that divine source. ${ }^{35}$ Understood as such, religion is a basic human good, a possible reason for acting. ${ }^{36}$ And, in principle, it can be exercised in any associational or group context.

Of course, whether religion on this account should be exercised in any, or a particular, group context is an open question. But, the open question is exactly the sort of query most appropriate for adjudicating disputes that involve a good so fundamental for human well-being and (potentially) so encompassing of all aspects of life. ${ }^{37}$ The paradigm of voluntary association prematurely 'closes' that question by offering a narrow set of principles which (too) quickly discerns (what it considers to be) morally and organizationally appropriate contexts for corporate religious exercise. But, we wonder: is that narrow set of principles-concerning autonomy, state sovereignty, and religion re- or ill-conceived-truly sufficient? Does it not short circuit one's practical reasoning over the possible and morally appropriate ways to find, and to respond to, the ultimate truth of things? Unable to pursue a comprehensive critique of political liberalism(s) here, let us now turn to a further criticism of the voluntary association paradigm.

Given its political liberal emphases, and despite its group ontological agnosticism, the paradigm of voluntary association inevitably lends itself to reductive group ontological positions that foster moral distractions of various kinds. ${ }^{38}$ The most problematic of these positions is the one which, when (subtly) imposed upon religious communities, makes those groups understand themselves as little more than aggregations of consenting individuals - that is, voluntary associations. Political liberals, of course, may claim that the paradigm does not 'postulate that religious groups are (ontologically) voluntary associations. ${ }^{39}$ But when groups such as the United States Conference of Catholic Bishops adopt voluntarist models to defend their institutional rights, ${ }^{40}$ we can reasonably conclude that the paradigm has real consequences

John Finnis, Religion \& Public Reasons: Collected Essays, vol 5 (Oxford University Press 2011) 35.

34 ibid 29.

35 ibid 81-82.

36 Finnis (n 28) 90.

37 ibid.

38 Legal scholar James D Nelson, for example, argues that viable claims of 'corporate conscience' are enjoyed by groups that foster close identification between members and their group roles (such as families, wherein women closely identify with the role of mother). This position restricts or reduces group agency to certain types of groups for religious liberty purposes. James D Nelson, 'Conscience, Incorporated' [2013] Michigan State Law Review 1568. Justice Ginsburg offers a more radical position. She claims that artificial entities cannot exercise religion and thus cannot enjoy religious exemptions. She fails to make clear, however, that even religious communities incorporate under state law and thus, in a certain sense, are artificial entities as well. If followed to its logical conclusion, her position would withhold religious exemptions from houses of worship. Burwell (n 2) 2793-94.

39 Laborde (n 5) 173.

40 Ad Hoc Committee for Religious Liberty, USCCB, 'Our First, Most Cherished Liberty: A Statement on Religious Liberty’ 5 <http://www.usccb.org/issues-and-action/religious-liberty/upload/Our_First_ 
upon collective self-understanding. Moreover, while some commentators might welcome this imposition as morally appropriate - as, say, fulfilling Rawls's proviso ${ }^{41}$ we should be mindful of the believer's perspective. For individuals that see themselves as belonging to an organic entity ${ }^{42}$ or to a corporate body constituted by a force other than themselves, ${ }^{43}$ the voluntary association model can impose upon their religious beliefs and practices. For them, there may be more moral distraction than a promised clarity.

\section{B. Group Ontology Within Practical Reason}

I have just examined two group ontological paradigms that are morally distracting by virtue of their underlying methods of corporate rights ascription. Now I turn to a group ontology that can avoid moral distraction precisely because it rests within practical moral reasoning itself. This is the group ontology found within the classical natural law tradition, and my general aim here is to begin to show how its fundamental link to morality can inform our methodological approach to corporate religious liberty.

To start, recall the political liberal preference to subordinate the query concerning what groups are (group ontology) to that concerning social relations (moral reasoning, broadly understood). ${ }^{44}$ As deployed by proponents of the voluntary association paradigm, this subordination permits corporate rights ascription, and even our conception of what groups are, to be driven by a narrow set of normative principles. Hence, we see (i) political liberal proposals to restrict corporate religious freedoms to certain kinds of voluntary association and to withhold them from for-profit firms, and (ii) a certain political liberal ease with, or imposition of, reductive forms of group ontology. Neither result avoids moral distraction; however, since, as argued above, the first turns upon a suspect treatment of 'religion' (among other things) and the second a disregard for the believer's point of view.

Nevertheless, it must be admitted that the subordination of the group ontological to the moral is not entirely misguided. For one, it can avoid problematic 'standard argument' reasoning. But, more significantly: if we can understand the 'sub-ordination'

Most_Cherished_Liberty.pdf > accessed 1 August 2019 (defending church autonomy by claiming that religious institutions display the 'American genius for voluntary associations').

41 John Rawls, 'The Idea of Public Reason Revisited' (1997) 64 The University of Chicago Law Review 765, 783-84.

42 Corp of the Presiding Bishop v Amos [1987] United States Supreme Court 107, SCt 2862, 2871-72. In a concurring opinion, Justice Brennan writes: 'For many individuals, religious activity derives meaning in large measure from participation in a larger religious community. Such a community represents an ongoing tradition of shared beliefs, an organic entity not reducible to a mere aggregation of individuals.'

43 For Roman Catholic conceptions of the Church as a moral or supernatural person, see Henri de Lubac, Catholicism: Christ and the Common Destiny of Man (Lancelot C Sheppard trs, Universe Books 1962) 19; Joseph Ratzinger, 'The Ecclesiology of the Constitution Lumen Gentium' in Henry Taylor (trs), Pilgrim Fellowship of Faith: The Church as Communion (Ignatius Press 2005) 148, fn 18; Guy Mansini OSB, 'Lumen Gentium' in Matthew Lamb and Matthew Levering (eds), The Reception of Vatican II (Oxford University Press 2017) 52. For ecumenical sources on the church's personality, see Labordeed running head is okay.,William T Cavanaugh, 'Are Corporations People? The Corporate Form and The Body of Christ' in Field Hospital: The Church's Engagement with a Wounded World (William B Eerdmans 2016) 13-31. 
involved to entail a genuine ordering of group ontology under morality itself (and not under a narrow and suspect set of normative commitments), then we have the opportunity (i) to understand what groups are to the best of our ability, and (ii) to explore the full range of practical moral considerations implicated by corporate religious exercise. In other words, we have the opportunity to actively affirm a group ontology, while drawing attention to the 'underlying facts and interests that ought to guide our legal and moral assessment'. ${ }^{45}$ This opportunity, I propose, is offered by a natural law conception, or sub-ordering, of group ontology.

We look then to John Finnis's treatment of groups, which, among interpretations of Aquinas on the subject, is by far the most thorough and systematic. ${ }^{46}$ According to Finnis (though departing somewhat from his exposition), ${ }^{47}$ Aquinas understands groups in relation to their actions. This entails viewing the actions engaged in as executed by flesh-and-blood individuals, and not by group organisms or substantial wholes (for what can those be?). As Finnis notes, 'Aquinas ... has a quick, dialectical argument to show that human groups and societies are not natural bodies, organisms, or substances $\{$ unum per se\}: some acts of group-members are not acts of the group [as when a soldier disobeys a military command] and some acts of a group are not the acts of any of its members [as when an army surrounds the enemy], 48

The elimination of a certain organicism, however, does not mean that Aquinas views groups themselves as fictions, as 'a "manner of speaking” useful for ascribing to individuals ... some culpability or liability for the acts of others' ${ }^{49}$ A genuine realism pertains to the group itself because the group on Aquinas's account is 'a kind of whole', 'a unity of order'. ${ }^{50}$ Finnis explains:

What, then, is a human group's 'order'? Why does such order make the group unified, one, a whole? Order of this kind has ... two kinds of element. There is (A) the interrelationship(s), the co-ordination, between the members of the group (the parts of the whole). More importantly and fundamentally, there is (B) the relationship between the group and the purpose or point (finis, 'end') of the associating-together and co-ordination by its members which makes it a group. ${ }^{51}$

Thus, we see that a group consists of parts, which are coordinated around a purpose. It is the purpose especially that provides a reason for the parts to come together, to be coordinated into a real 'unity of order'. 52

At this point, we must step back to identify the context in which Aquinas speaks of groups as 'a unity of order' or a coordination of parts. Finnis notes that this takes

45 Laborde (n 5) 172.

46 For another commentator on Aquinas and groups, see Thomas Gilby, Principality and Polity: Aquinas and the Rise of State Theory in the West (Longmans, Green and Co 1958) 255-56.

47 For Finnis's most systematic presentation of Aquinas on groups, see John Finnis, Aquinas: Moral, Political, and Legal Theory (Oxford University Press 1998) 23-29.

48 ibid 27, 24-25.

49 ibid 27.

50 ibid 24

51 ibid 25 (emphasis in original). For primary sources, see 23-28, fns 9-28.

52 ibid 24. 
place especially in the prologue to the second part of the Summa Theologiae (where Aquinas focuses upon 'people precisely as principium, source, of their own deeds, having free choice ... and power ... over those deeds') and in the prologue to Aquinas's commentary on Aristotle's Ethics (which presents a 'philosophy of human affairs', a 'treatment [that] seeks to describe and explain the behaviour of individuals and societies'). ${ }^{53}$ Common to both texts is actio (a 'doing ... considered precisely as self-determining ${ }^{54}$ ), which is the core subject-matter of philosophia moralis ('the sciences of the order we can bring into our deliberating, choosing, and voluntary actions $^{55}$ ).

Thus, situated within moral philosophy, Aquinas's group ontology can be conceived of in at least two ways. First, for Aquinas, groups are most fundamentally understood in terms of self-determining actions and, hence, 'a theory of society or associations can be counted as part of moralis philosophia'. ${ }^{56}$ Second, we see that Aquinas also understands groups in terms of the concrete things (the 'elements such as individual persons, families, and neighbourhoods') that are coordinated. Consequently, the sciences that Aquinas incorporates into moral philosophy-economics, politics, and law-are provided with subject-matters that are distinct, but not entirely divorced, from self-determining actions per se. ${ }^{57}$ In other words, we see that Aquinas's group ontology understands groups as both (i) social actions, which are subject to moral evaluation, and (ii) things, which are studied within moral philosophy's related family of social theories or sciences.

What this two-fold perspective means for corporate rights ascription can now be made plain. No longer must we view group ontology as separate from, and distracting for, moral deliberation. Instead, we are invited to view the moral evaluation of groups (understood as social actions) as grounding the ascription of legal rights to groups (understood as concrete things). Thus, the conditions under which we might appropriately extend legal rights to groups will be a matter of moral deliberation. And, notably, such deliberation involves neither an agnosticism towards group ontology (it in fact suggests a particular form), nor an imposition upon those who may subscribe to a different ontology (so long as they can accept the moral use of a natural law conception), nor the prescription of a narrow set of moral principles (whether concerning corporate personality or political liberal commitments) that risks short circuiting practical moral reasoning. Based on these considerations alone, we can begin to see how a natural law approach to corporate rights ascription follows a methodology that is far superior to the metaphysical and empirical methods discussed above.

So much for our first defence of group ontology's place within the ascription of corporate rights. In the next section, I offer a second defence, showing how a natural law ontology can be used in place of inadequate rights-based moral analyses. 


\section{A NATURAL LAW ACCOUNT OF GROUP RIGHT}

Now that we know how groups are understood within the natural law tradition, we are able to consider in more detail how the tradition's two-fold group ontologythrough which groups are seen as both actions and things - can influence the ascription of corporate rights. Keeping in mind the distinction between legal and moral (or natural) rights, ${ }^{58}$ there are at least four ways in which this investigation may proceed: we could examine the ascription of legal rights to (A) groups as actions and/or to (B) groups as things; or we could examine the ascription of natural rights to (C) groups as actions and/or to (D) groups as things.

Among these options, I suggest we focus upon the third-(C) the ascription of natural rights to groups as actions - for two reasons: first, natural law and natural rights are commonly associated, and so option $\mathrm{C}$ provides a familiar place for us to start; second, the ascription of rights to actions, as opposed to rights-holding things, is counterintuitive and even unintelligible, thus option $\mathrm{C}$ provides an intriguing and (as we will see) a morally illuminating point of departure.

Taking this third option, then, we ask: how can we intelligibly ascribe natural rights to actions, that is, to groups understood as verbs? Further: what benefits does such ascription provide, especially for disputes over corporate religious freedoms? Below I answer each question, in turn, with the hope of not only defending further the use of group ontology within corporate rights ascription, but also of articulating a viable and nuanced account of group rights as understood within a natural law framework.

\section{A. From Natural Rights to Group Rights}

So how can we ascribe natural rights to actions or, differently put, to groups understood as verbs? In short, we cannot. To explain why, and to see how we might find a 25 positive account of group rights, we turn again to Finnis's theory of natural law.

Among recent articulations of the classical natural law tradition, John Finnis's Natural Law \& Natural Rights is perhaps the most comprehensive. ${ }^{59}$ One noticeable omission, however, is explicit treatment of the nature or logic of group rights, whether natural or legal. Chapter 8 (simply entitled 'Rights') discusses moral rights, rights-talk, duties, the common good, rights specification, equality and respect, and, finally, absolute human rights. At no point in this discussion, however, does Finnis explicitly hold out groups to be subjects, or holders, of natural rights. And, with regard to legal rights, the group as rights-holder is seldom directly mentioned. What accounts for this omission? And how might the reasons behind it affect our understanding of group rights in general?

Focusing upon the nature of natural rights themselves, we can answer the first question rather succinctly: since (i) the logic of rights involves person A having a claim or liberty against person $\mathrm{B}$ with respect to action $\mathrm{X}^{60}$; and since (ii) only natural persons, in the classical sense, ${ }^{61}$ can hold natural rights; and since (iii) groups 
are not persons in the classical sense $\mathrm{e}^{62}$; it follows that (iv) the logic of natural rights precludes groups from being natural rights-holders.

So, the omission of 'natural group rights' is justified when we consider the logic of natural rights along with an ontology that resists an organicist understanding of groups. We do not stop our investigation here, however, since we must still explain how these reasons (that is, the above logic and ontology) might affect, and indeed positively shape, our understanding of group rights in general. In other words, now that we have eliminated the possibility of 'natural group rights' (option D in the introduction to this section), what viable alternative(s) do we have?

Based on a growing literature on group agency and rights, it seems that there are many alternatives from which to choose. Not all of these alternatives, however, are at home within the classical natural law tradition. ${ }^{63}$ Therefore, for our purposes, I offer two plausible ways in which we might take the logic of natural rights, along with a natural law group ontology, to account for the nature of group rights.

The first way involves bringing the idea of the 'group as social action' to its logical conclusion within a natural rights framework (option (iii) above). Recall that the logic of natural rights involves (natural) person A having a claim or liberty against (natural) person $\mathrm{B}$, with respect to action $\mathrm{X}^{64}$ On a natural law account, groups cannot stand in the place of natural person A or B. So their only possible fit within this logic is at the term 'action X'. Although seemingly counterintuitive, this placement makes sense if we take seriously the tradition's ontology which, as Finnis states, considers a group to be 'an order of human, truly personal acts'. ${ }^{65}$ Thus placed, groups as social actions are not the subjects (the rights-holders or duty-fulfillers) of natural rights. Rather, they are the objects to which persons have natural rights and duties.

Now we can newly appreciate the various social goods to which the natural law tradition claims natural rights: for example, the rights to marry and to raise children $^{66}$; to coordinate in communities of business, play, and friendship ${ }^{67}$; to engage in, and benefit from, political and intermediary societies. ${ }^{68}$ Insofar as these goods involve the 'coordination of activity by a number of persons, in the form of interactions, and with a view to a shared objective," 69 then they imply the idea of group right - that is, morally right social action. Differently put, we might understand this idea to entail natural rights held by individual persons to do things which contribute to human well-being in an intentional, coordinative manner. This, I suggest, is a logical conclusion of situating the idea of the 'group as social action' within a natural rights framework.

62 Finnis (n 47) 27; Finnis (n 18) 95, 98.

63 For example, while Christian List and Philip Pettit outline an account of group agency that is compatible with a natural law ontology, they endorse a normative individualism which may not translate well into a natural law account of natural rights. See Christian List and Philip Pettit, Group Agency: The Possibility, Design, and Status of Corporate Agents (Oxford University Press 2011) 182.

64 For alternative conceptions of the logic of (natural or legal) rights, see, eg Joseph Raz, 'Right-Based Moralities' in Jeremy Waldron (ed), Theories of Rights (Oxford University Press 1984) 183.

65 Finnis (n 18) 95.

66 Finnis (n 28) 86.

67 ibid 139-44.

68 ibid 144-50.

69 ibid 153. 
To better appreciate this account of group rights, let us turn immediately to a second way in which we might understand the nature of group rights. More conventional than the first, the second way simply entails the assignment of legal rights to groups, in light of a separate and supporting moral analysis (thus we reach options (i) and (ii) in the introduction above). Here, the idea of group right does at least two things. First, by drawing attention to the action around which individuals coordinate and to which they claim legal rights, the idea of group right encourages reflection upon the moral character (or rightness) of the act in question. In doing so, it provides a supporting moral analysis that focuses upon the natural rights of individuals; thus, it provides a much needed moral specificity for legal protections that are phrased in terms of rights to (do) something. Hence, a legal right to free religious association is morally understood in terms of this or that person's natural right to associate for religious reasons. ${ }^{70}$ This is a more illuminating way of understanding the moral stakes of legal group rights, especially when compared to the morally unspecified and arguably unintelligible idea of 'natural group rights.'

A second use afforded by the concept of group right is its application to both sides of a natural law group ontology - that is, to groups understood as actions and to groups understood as (legal) rights-holding things. The idea of group right can therefore work effectively within legal regimes that recognize rights to certain types of actions, without paying immediate attention to the 'person(s)' involved. This provides space for practical reasoning to determine the best course of action in circumstances involving the possible assignment of legal group rights. We see such discretion in Judge Jordan's dissent in Conestoga Wood Specialties v HHS.

Faced with the (then) unusual situation of extending free exercise rights to a closely held for-profit corporation, Judge Jordan suggests emphasizing the action at stake, over the particular 'persons' implicated. He writes:

Given the special place the First Amendment plays in our free society, the Supreme Court in Bellotti instructed that, instead of focusing on 'whether corporations "have" First Amendment rights and, if so, whether they are coextensive with those of natural persons,' 'the question must be whether' the activity at issue falls within an area 'the First Amendment was meant to protect.' ... In other words, the operative question under the First Amendment is what is being done - whether there is an infringement on speech or the exercise of religion- not on who is speaking or exercising religion. ${ }^{72}$

The concept of group right works with Judge Jordan's 'operative question' in so far as that query assumes the moral propriety of, or natural rights to, the action under

71 To account for moral group rights, Dwight Newman, for example, proposes the nuanced idea of a group's 'moral status', which helps avoid problematic metaphysical implications attending to the concept of a group's 'moral personality'. Dwight Newman, Community and Collective Rights: A Theoretical Framework for Rights Held by Groups (Hart Publishing 2011) pt II.

72 Conestoga Wood Specialties v HHS (2013) 724 F3d 377, 402-03 (3rd Cir) (holding that business owners could not make First Amendment or RFRA claim against government's contraceptive mandate) (Jordan, J, dissenting) (citing First National Bank of Boston v Bellotti (1978) 435 US 765, 776 and 777). 
consideration (here, corporate religious exercise). However, it is important to note that the concept of group right ultimately rejects a moral agnosticism towards the persons implicated; indeed, ethically speaking, it holds that flesh-and-blood individuals ('natural persons') are morally paramount. Nevertheless, the underlying point remains: we can protect that which is morally right (or that to which there are natural moral rights) through the extension of legal protections to natural or artificial corporate persons. Thus, we see that the ability to work from (right) actions to (legal) rights-holding aids the practical deliberation involved in the assignment of legal group rights: it permits that deliberation to move freely and fully across the moral and ontological realities involved, in order to creatively determine and to prudently assess the possibilities for legal protection. ${ }^{73}$

We began this section by asking how we might intelligibly ascribe natural rights to groups when understood on a natural law account as social actions. We now see that the logic of natural rights precludes discussion of 'natural group rights' and instead invites us to consider group protections in two constructive ways: first and fundamentally, within the concept of group right (those social acts to which individual persons have natural rights) and, second, within a standard framework of legal group rights (legal rights ascribed to actions or persons, in light of a supporting moral analysis). We might say then that a natural law account of group rights is, at bottom, an account of right social action - that is, of group right.

\section{B. Group Right and Corporate Religious Liberty}

Now to our second query: what benefits does the concept of right social action, or group right, provide? In the corporate religious liberty context, there are two significant challenges that the idea of group right can help overcome. These include the polarization of contemporary rights discourse and the under- and over-inclusion of organizational protections.

Consider the problem of polarization. The contemporary debate over corporate religious liberty is often framed in terms of two opposing camps: those who advocate the rights of individuals over groups (eg proponents of the voluntary association paradigm) and those who are seen to do the opposite (eg proponents of the corporate personality paradigm). ${ }^{74}$ The existence of both camps is not in itself problematic. Rather the problem rests with the impasse created when each side fails to find common ground (and thus reasonable means of accommodation) by relying extensively upon rights-claims to assert their preferred policy positions. ${ }^{75}$ So what is it about rights-talk that so entrenches each side against the other?

The possessive, and often exclusionary, nature of rights is partly to blame. Thomas Hobbes, for instance, is said to view human nature in terms of highly individualistic rights. As Macpherson notes, Hobbes 'reduces ... human essence to

73 See Section 4C below.

74 Describing the contemporary debate in similar terms, see Schragger and Schwartzman (n 25) 919-20; Schragger and Schwartzman (n 5) 345.

75 For commentary on the polarization of the contemporary debate, see Douglas Laycock, 'The Campaign Against Religious Liberty' in Schwartzman, Flanders and Robinson (eds) (n 5); Paul Horwitz and Nelson Tebbe, 'Religious Institutionalism - Why Now?' in Schwartzman, Flanders and Robinson (eds), ibid. 
freedom from others' wills and proprietorship of one's own capacities'. ${ }^{76}$ In the context of associations, these claims translate into a 'freedom from any relations with others except those relations which the individual enters voluntarily with a view to his own interest'. ${ }^{77}$ Applying these 17th-century principles to today's debates, one can see how a theory of rights based upon them encourages a sharp distinction between 'mine' and 'thine', with the rights-holder emphasizing the former even at the expense of the latter.

Furthermore still, it is easy to see how the rights-claims of groups are deemed largely unintelligible, or morally egregious, when viewed against a Hobbesian framework. Indeed, in so far as rights-claims gain their normative currency from a Hobbesian anthropology, it is difficult to ground a group's rights in anything other than the possessive individual. Against this backdrop, the rights of the corpus mysticum or any corporate moral person are treated in one of two ways: they are either (i) forcibly translated into the rights of individuals, thus (for some believers) leaving only Locke's 'true church' ('a voluntary society of men, joining themselves together of their own accord') but stripped of its theological and normative significance ('the public worshipping of God ... [and] the salvation of their souls ${ }^{78}$ ); or they are (ii) nevertheless asserted in terms of original group rights, that is, rights that a group itself somehow possesses. The clash of rights is thus inevitable.

But the possessive substance of rights-talk is not the only source of blame. Polarization is also caused when rights-talk forgets about moral virtues and other nonrights-based reasons for acting. Regrettably, it indeed tends to forget these. According to Joseph Raz, it is a common view that 'one ought to do that which one has a duty to do but that one does not always have a duty to do that which one ought'. He explains: 'Thus, while I ought to allow my neighbour who locked himself out of his house to use my phone, I have no duty to do so. On the other hand, since I have promised my neighbour to saw off ... a branch overhanging a corner in his garden, I have a duty, and therefore I ought, to do so. ${ }^{, 79}$ Raz's illustration points to 'the moral significance of ordinary reasons for action', reasons which (to reiterate) do not always involve the fulfilment of one's duty. Indeed, there may be no duty at all, thus no corresponding right. ${ }^{80}$

Moreover, rights-talk does not recognize the intrinsic value of moral virtues. 'Again the reason is much the same as before', Raz notes. 'None of the commonly recognized virtues ... consists in discharging one's duties or being disposed to do so. Honesty is a virtue which is particularly closely tied to the duty not to deceive, and yet even it is not exhausted by compliance with the duty. ${ }^{, 81}$ Here, too, Raz contends that rights-talk suppresses the true moral significance of virtues and other non-rights-based reasons for acting. He concludes: '[R]ight[s]-based theories (like utilitarian theories) cannot allow personal characteristics which are virtuous or morally praiseworthy to be judged intrinsically desirable and cultivated for their

76 CB Macpherson, The Political Theory of Possessive Individualism (Oxford University Press 1962) 264.

77 ibid 263.

78 John Locke, The Reasonableness of Christianity: As Delivered in the Scriptures (John C Higgins-Biddle ed, Oxford University Press 1999) 110-11.

$79 \operatorname{Raz}(\mathrm{n} 64) 184$.

80 ibid.

81 ibid 185. 
own sake. ${ }^{82}$ Instead, those characteristics or reasons for acting are always seen to serve another end-namely, my rights.

So rights-talk tends towards polarization, and any debate that utilizes rights-talk will most likely follow suit-often to poor moral results. In the corporate religious liberty context, these results are perhaps seen most clearly in an under- and overinclusion of organizational protections. Thus, we return to our criticism of the voluntary association paradigm and the corporate personality paradigm from Section 2. By stressing the rights of individuals, proponents of the former typically exclude too many groups from the ambit of corporate religious liberty, including for-profit firms or charities that, all things considered, usefully serve individuals of various religious backgrounds. ${ }^{83}$ And by emphasizing the rights of groups, proponents of the personality paradigm typically include all sorts of organizations within corporate religious liberty's domain, notwithstanding ethically relevant circumstances that may speak to the contrary. ${ }^{84}$ All the while, both sides continue to assert their rights, and the individual-group divide grows larger still. Can the concept of group right help improve this situation?

There may be room for doubt. It might be claimed that the idea of group right cannot actually overcome the problems above, since it too trades on the currency of individual rights. As such, it already weighs in favour of an individualist position, and thus its moderating intervention is no such thing. ${ }^{85}$ This criticism misses the mark, however.

It is true that the idea of group right has recourse to the rights of individuals. But, the rights referred to are not those of the possessive individual, whose freedom is defined by an independence from, or a power over, others. ${ }^{86}$ Rather, the rights implicated follow from the classical natural law conception of man, understood as socially dependent and integrated. ${ }^{87}$ Insofar as the idea of group right refers to natural rights of this kind, it neither endorses radically individualist conclusions nor precludes the moral significance of human sociality. In principle, it can serve as a bridge for the individual-group divide.

Natural rights on the classical account also do not exhaust moral reasoning in the way that (some theories of) Hobbesian or possessive rights can. While possessive rights typically fail to see the moral significance that inheres to the virtues and other 'ordinary reasons for action', 88 natural rights recognize goods that are intrinsically

82 ibid 186.

83 Laborde (n 5) 171 (describing overly generous, or organizationally wide, collective freedoms to be 'exorbitant', in conflict with 'individual freedom and rights against discrimination').

84 This position is attributed to the so-called 'religious institutionalists'. Among them, Schragger and Schwartzman identify Víctor Muñiz-Fraticelli, Paul Horwitz, Patrick McKinley Brennan, Steven D Smith, and Richard W Garnett. See Schragger and Schwartzman (n 5) 348, fn 1.

85 Joan Lockwood O’Donovan, 'Christian Platonism and Non-proprietary Community' in Bonds of Imperfection (Wm B Eerdmans 2004) 73-74 (noting how rights language has an 'inescapable association' with the concept of individual, possessive rights).

86 Macpherson (n 76) 37-38.

87 Jacques Maritain, The Rights of Man and Natural Law (The Centenary Press 1944) 44-45 (highlighting the social character of human rights); Finnis (n 28) 210-18 (emphasizing the social character of justice and detailing what the common good entails). See also ST I-II q 90 a 4 (noting the inherent communal purpose(s) of law and, by extension, rights). 
worthwhile (as is the case with any basic form of human $\operatorname{good}^{89}$ ) as well as goods that cannot be exhausted (or entirely used up) by individuals, whether alone or in groups. As Finnis notes, 'public morality and public order ... are both diffuse common benefits in which all participate in indistinguishable and unassignable shares' ${ }^{90}$ The enjoyment of natural rights therefore requires a view towards the good that (objectively) exists outside of the human subject. Its moral purview extends beyond the rights-claiming individual.

A grounding in natural rights does not inevitably place the idea of group right within a radically individualist camp. What then are its moderating effects? Perhaps the most important effect is its primary emphasis upon actions, as opposed to individual- or group-rights-holders per se. Constituting the first use of a natural law account of group rights, ${ }^{91}$ the concept of group right provides a moral analysis of right social action. Such analysis is necessary if legal prescription is to identify accurately what is morally owed to whom in a given corporate religious liberty dispute. This specification (we now add) occurs when we translate a two-term rights relation-between 'a (class of) persons and a (class of) subject-matter' - into its corresponding three-term relations. ${ }^{92}$ Hence, we might say that a right to free religious association (a class of subject-matter) bears upon believers A, B, C, etc (class of persons 1), affected third parties (class of persons 2), and a local government (class of persons 3). From this, various three-term (natural) rights relations can be identified, thereby encouraging a careful assessment of the moral stakes involved.

What an emphasis upon right social action does therefore is to stop moral and legal deliberation from jumping straight from dispute to (legal) rights ascription. It slows down and refines this process by first asking 'What is the right thing to do?' and not 'Whose right wins?' This shift from 'rights' to 'right action' has the potential to improve moral discourse, leading to better religious freedom policies and corporate rights ascriptions. The more a natural law account of group right can bring this about, the more reason there is to adopt it.

\section{LEGAL CONDITIONS FOR RIGHT SOCIAL ACTION}

In the previous section, I offered a second defence of group ontology's use in corporate rights ascription. I did so by drawing attention to the concept of group right, then explaining how that concept grounds a natural law account of legal group rights. Building upon that account, I now demonstrate what the movement from group right to legal prescription could look like in more detail. This procedure, I suggest, consists of three stages. First, it involves attentiveness to the 'anatomy' of a natural law group; second, an assessment of the moral rectitude or rightness of the group or social action; and, finally, a determination of broad legal conditions that may appropriately bring about or limit the act in question. In this section, I provide an overview of each stage, and I very briefly discuss the procedure's practical benefits in relation practical reasonableness and religion), 92 (noting that a given basic good is not instrumental in the pursuit of any other good).

90 ibid 216.

91 See above Section 3A.

92 Finnis (n 28) 218. 
to various contemporary disputes over corporate religious freedoms. My aim in this section therefore is to bring the major theoretical discussions of this article to a somewhat more practical, and still morally illuminating, culmination.

\section{A. The 'Anatomy' of a Natural Law Group}

Recall that a group on Aquinas's account is 'a unity of order', 93 which, through the lens of moral philosophy, can be understood in terms of self-determining actions and concrete rights-holding things - eg coordinations of families, neighbourhoods or, especially, rights-holding individuals. ${ }^{94}$ Generally speaking, movement from the first perspective to the actual ascription of legal group rights proceeds straightforwardly: it begins with a moral assessment and concludes in a particular assignment of legal 10 rights.

More closely viewed, however, we see that this movement is slightly more complex: it begins with the component parts, the 'anatomy', of Aquinas's group; afterwards moral deliberation bears upon that anatomy in order to prescribe basic conditions within which a group (or social action) can exist (or take place). On this more nuanced approach, corporate rights ascription is less a matter of simply assigning legal rights to this or that group. Instead, it is more a matter of creating conditions in which individuals can coordinate for shared (religious) purposes in a morally appropriate way. I will discuss the moral significance of this particular emphasis in Section 4C below. For now, let us return to Aquinas's group ontology to identify the 'anatomy' therein.

Finnis identifies 'two kinds of elements' that constitute Aquinas's group. First, there is the purpose that gives point to individuals' coordinating together. Second, there is the actual coordination (the 'interrelationships', 'factors co-ordinated', or 'patterns of association') identified between the group's individual members ('the parts of the whole').95 Elaborating upon this basic 'anatomy', Finnis notes two subelements within a group's coordination: the group's public policy ('a policy which the relevant members choose to participate in' to achieve the group purpose) and its rulers (those who 'define what shall be the public policy co-ordinating the future actions of relevant members'). These sub-elements are particularly important because without them the group itself would not truly exist. ${ }^{96}$ The reason for this pertains to the idea of consent.

Building upon Finnis's interpretation, Richard Ekins notes that all groupmembers must consent to the terms of coordination (the public policy and rulers) in order for the group itself to exist. Without unanimity of consent, the group lacks intentional coordination and might simply be a mob or a collection of individuals with shared traits, but no shared intention to act jointly. ${ }^{97}$ With that unanimity, however, the group is indeed real, far from a fictional concept used to describe an aggregate of

93 Finnis (n 47) 24.

94 ibid 21.

95 ibid 25-26.

96 ibid 28.

97 Richard Ekins, The Nature of Legislative Intent (Oxford University Press 2012) 63, 70. For further discussion of consent, especially of joint intention, see, eg Michael E Bratman, Shared Agency: A Planning Theory of Acting Together (Oxford University Press 2014) 9-12; Margaret Gilbert, Joint Commitment: 


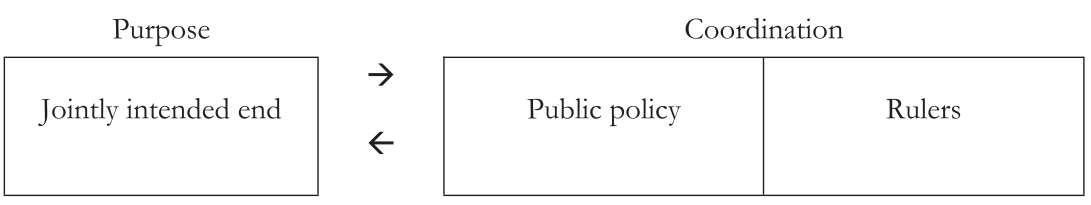

Figure 1.The 'anatomy' of Aquinas's group.

individual inputs. ${ }^{98}$ In this case, group-agential language, such as 'This group intends $\mathrm{X}$, is not metaphorical. It is to be taken literally. ${ }^{99}$ And, thus, not only can we refer to Aquinas's group in realist terms, but we can also attribute (legal) rights to the group itself since it exists in a manner distinct from its individual parts.

Figure 1 illustrates the 'anatomy' of Aquinas's group. The arrows indicate the reciprocal relationship between a group's major elements: its purpose and coordination. Whether self-determining actions or concrete things, these parts (when coordinated) constitute what Aquinas and the classical natural law tradition call a group.

\section{B. Doctrines of Corporate Religious Liberty}

So much for the 'anatomy' of Aquinas's group. We now turn to the second and third stages of our procedure of corporate rights ascription. In the second stage, we note general criteria by which the natural law tradition would judge a social action, specifically in religious liberty contexts, to be right or wrong. In the third stage, we identify broad legal conditions that may appropriately bring about or limit a (religious) social act.

\section{(i) Practical Reason and Specific Moral Norms}

An overview of a natural law morality, in which we find the requirements of practical reason and a wealth of specified moral norms, is outside the scope of this article. Nevertheless, we do require some basic guidance for the moral evaluation of groups in corporate religious liberty contexts. For our purposes, a few points will suffice.

First, recall that our approach to corporate rights ascription is grounded in the moral concept of right social action (or group right), which is made intelligible and specified by the natural rights of individuals. Natural rights (we now add) are but translations of the requirements of practical reason. ${ }^{100}$ And these requirements are what constitute 'ethics', classically conceived as an enterprise in determining how to bring to bear basic forms of human good 'upon particular projects, dispositions or actions. ${ }^{101}$ These requirements concern 'what one must do, or think, or be' if one is to participate fully in all the 'basic aspects of human well-being'. Thus, the

How We Make the Social World (Oxford University Press 2014) 1-10; John R Searle, Making the Social World: The Structure of Human Civilization (Oxford University Press 2010) 42-60.

$98 \quad$ Finnis (n 47) 28.

99 The literalness of group-agential language is a feature of group realism, in general. See List and Pettit (n 63) 7-11.

100 Finnis (n 28) 198.

101 ibid 101. 
requirements work from 'the first (pre-moral) "principles of natural law" to articulate what morally ought, or ought not, to be done in the pursuit of human goods. ${ }^{102}$

In the context of religious liberty disputes, and indeed in any context, the following of these requirements entails respect for every good and no arbitrary preference among them or among the persons who pursue them. ${ }^{103}$ Implicated as well is the 'fostering [of] the common good of one's communities'. ${ }^{104}$ Such requirements provide basic moral guidance for the retrospective or prospective determination of how to act reasonably when various, and seemingly competing, goods are at stake. Practical reasoning ought to have recourse to these, and the full range of, requirements when approaching corporate religious liberty disputes. However, as stated, these requirements are rather general and thus seem to necessitate further specification in order to bring them practically to bear upon particular circumstances. This brings us to a second point.

Earlier I discussed the narrow set of normative principles that some political liberal approaches to religious freedom endorse. We must now be clear that the problem involved is not the selection of only a few principles, as if number alone were the problem; rather, the problem lies with the choice or articulation of principles of narrow moral substance. In contrast to restrictive principles concerning autonomy rights, for instance, the requirements of practical reason seek to respect the full range of human goods, even when specified into particular moral norms. What might these specific moral norms look like in a religious liberty context? I propose three norms which are familiar to the natural law tradition and which stand in rather stark contrast to certain political liberal counterparts.

The first holds that religion (entailing one's relationship with God or the divine $^{105}$ ) is to be respected. ${ }^{106}$ This differs from limited protections granted to religion re- or ill-conceived. ${ }^{107}$ The second norm holds that a political community, or state, ought to defer to a group's internal authorities in matters relating to its own common good, thus pushing against statist or top-down approaches to social life. ${ }^{108}$ The third norm nuances the second and holds that the state can interfere with group activities, but not arbitrarily and only when justified by practical reasonableness. This final

102 ibid 102-03 (emphasis in original).

103 ibid 118, 105-06 (Finnis's seventh, third, and fourth requirements of practical reason).

104 ibid 125 (the eighth requirement).

105 ibid 89. Relatedly, Aquinas defines religion as a moral virtue, manifested by specific rituals, such as prayer or adoration. See ST II-II q 81 a 5.

106 On the value of religion, see, eg Brian Davies, Thomas Aquinas's Summa Theologiae: A Guide \& Commentary (Oxford University Press 2014) ch 17; Etienne Gilson, The Christian Philosophy of St. Thomas Aquinas (1994th edn, University of Notre Dame Press 2010) ch 5. For comparable political liberal sources, which define religion variously, see, eg Kent Greenawalt, Religion and the Constitution, Volume 1: Free Exercise and Fairness (Princeton University Press 2006) 15-25; Christopher L Eisgruber and Lawrence G Sager, Religious Freedom and the Constitution (Harvard University Press 2007) 51.

107 See above Section 2A.

108 Finnis (n 28) 144-47 (on subsidiarity); Finnis (n 47) 237; Gilby (n 46) 262 (on non-state collective action). For comparable political liberal sources, see John Rawls, Justice as Fairness: A Restatement (Erin Kelly ed, Harvard University Press 2001) pt IV ('Institutions of a Just Basic Structure'); Seumas Miller, The Moral Foundations of Social Institutions: A Philosophical Study (Cambridge University Press 2010) ch 2 ('The moral foundations of institutions'). 
norm may or may not result in the same practical outcomes as certain political liberal visions of state (in)action. Its normative starting point, however, differs. ${ }^{109}$

Allow me to move now to a final point. It seems to me that a practical upshot of the specific moral norms just stated is their organizational inclusivity. In other words, the norms do restrict religious freedoms to a certain type or narrow class of groups, such as voluntary associations alone. At the same time, however, the norms do not suggest that such freedoms are unconditional or absolute. The third norm in particular implies that there are circumstances in which state interference upon a group's religious exercise will indeed be morally justified. One general class of circumstance, I suggest, involves the ethically relevant fact of internal religious pluralism - that is, the situation in which a group's membership is composed of individuals of diverse or no religious faiths, and in which the group exercise of religion may have significantly adverse effects upon certain (dissenting) group members.

Internal religious pluralism is just one feature that can ethically distinguish one class of group from another. In what follows, I consider how an application of the requirements of practical reason and of specified moral norms might bear upon this and other ethically salient facts tied to the 'anatomy' of groups. We thus reach the third stage in our procedure of corporate rights ascription, where we identify broad legal conditions that may appropriately bring about or limit a (religious) social act.

\section{(ii) Freedom of the Church}

Returning to the 'anatomy' of Aquinas's group, our procedure can now apply specific moral norms to a group's internal terms of coordination so that the group members might act with reference to those terms in order to fulfil a joint religious purpose. This involves making assumptions about member's intentions when acting towards a shared end and prescribing legal or state (in)action so that those intentions might culminate in the expected social act. Let us see how this procedure might play out with regard to two broad group contexts: first churches, then non-church organizations.

With regard to churches, let us assume: (i) that members intentionally coordinate for a distinctively religious end, (ii) that they consent to the group's authority procedures with regard to the religious group act, and (iii) that they agree in the first instance to internal adjudication over the (moral, theological, and even legal) propriety of the group act. All three assumptions speak to internal conditions necessary for the religious social action to occur: the first pertains to the group's purpose (which incidentally also suggests what sort of individuals would agree to participate in the group or social action, ie those who hold a shared religious vision); and the second and third assumptions relate to the group's coordination, indicating likely basic terms by which the individuals would choose to coordinate for their shared end.

How should the law or state respond? Three external legal conditions could support or facilitate the religious social action. They are: (i) state recognition of religious

109 Finnis (n 47) 222-28 (describing the limited moral purpose of a political state); Laborde (n 5) ch 4 (arguing that a political liberal state must justify its coercive laws through accessible reasons, promote civic equality, and protect personal liberty). 


\begin{tabular}{|c|c|c|c|c|}
\hline Purpose & & Coordination & & External legal conditions \\
\hline \multirow{3}{*}{ Religious end } & \multirow{3}{*}{$\begin{array}{l}\rightarrow \\
\leftarrow\end{array}$} & $\begin{array}{l}\text { (i) Collectively aim towards a } \\
\text { religious purpose or end }\end{array}$ & $\leftarrow$ & $\begin{array}{l}\text { (i) State recognition of } \\
\text { religious truth or value }\end{array}$ \\
\hline & & $\begin{array}{l}\text { (ii) Consent to church's authority } \\
\text { in religious matters }\end{array}$ & $\leftarrow$ & $\begin{array}{l}\text { (ii) State deference to church } \\
\text { authority }\end{array}$ \\
\hline & & $\begin{array}{l}\text { (iii) Expect internal adjudication of } \\
\text { church's religious actions }\end{array}$ & $\leftarrow$ & $\begin{array}{l}\text { (iii) State interference when } \\
\text { morally justified }\end{array}$ \\
\hline
\end{tabular}

Figure 2.A religious social action and a doctrine of freedom of the church.

truth or value, for example, through religious establishment or separation, ${ }^{110}$ (ii) state deference to the group's internal authority procedures, especially with regard to distinctively religious acts, and (iii) state interference upon the religious action only when morally justified. ${ }^{111}$ Comprising what I call a doctrine of freedom of the church, $^{112}$ these conditions follow from the specific moral norms articulated above. Differently put, they hold that: (i) a relationship with God, or 'religion'113 is deemed valuable, $^{114}$ (ii) non-state groups contribute to societal well-being, ${ }^{115}$ and (iii) the state appropriately serves as an umpire between inter- and even intra-group disputes. 116

Figure 2 illustrates a religious social action (its purpose and coordination) and a doctrine of freedom of the church (the external legal conditions). The arrows on the left indicate the reciprocal relationship between the group's purpose and coordination. The arrows on the right illustrate that each external legal condition facilitates, or limits, the coordinating intentions of the group members. Should the state drastically limit even one of these intentions, then the religious social action (the group) will not be able to take place (or exist) — at least, as intended by its members.

Next, I briefly consider Aquinas's group ontology as applied to a different group context: non-church organizations.

110 For a concise defence of religious state establishment in Britain, see Nigel Biggar, 'A Reply to Theo Hobson' (2012) 115 Theology 175, 175. For a discussion of American church-state relations, see Nicholas Wolterstorff, 'A Religious Argument for the Civil Right to Freedom of Religious Exercise, Drawn from American History' in Terence Cuneo (ed), Understanding Liberal Democracy: Essays in Political Philosophy (Oxford University Press 2012) 329-52.

111 External legal conditions (ii) and (iii) are typical in contemporary church autonomy doctrine. See Burwell (n 2) 2794-97; Christopher Lund, 'Free Exercise Reconceived: The Logic and Limits of Hosanna-Tabor' (2014) 108 Northwestern University Law Review 1183, 1183-234; Schragger and Schwartzman (n 25) 974-84.

112 I use the word 'doctrine' in moral and even theological sense. This usage distinguishes my account from a mere legal doctrine, which can be understood in positivist terms, that is, as the artificial result of judicial reasoning. Recent scholars describe both 'freedom of the church' (or 'church autonomy') and 'corporate religious liberty' in this latter sense. See Chad Flanders, Micah Schwartzman and Zoë Robinson, 'Introduction' in Schwartzman, Flanders and Robinson (n 5) xix. 


\begin{tabular}{|c|c|c|c|c|}
\hline Purpose & & Coordination & \multirow[b]{2}{*}{$\leftarrow$} & External legal conditions \\
\hline \multirow{3}{*}{$\begin{array}{l}\text { Mixed ends: } \\
\text { secular and }\end{array}$} & \multirow{3}{*}{$\begin{array}{l}\rightarrow \\
\leftarrow\end{array}$} & $\begin{array}{l}\text { (i) Not all members collectively } \\
\text { aim towards religious purpose, end }\end{array}$ & & $\begin{array}{l}\text { (i) State recognition of } \\
\text { religious truth or value }\end{array}$ \\
\hline & & $\begin{array}{l}\text { (ii) Not consent to authorities } \\
\text { when religious act poses harms }\end{array}$ & $\leftarrow$ & $\begin{array}{l}\text { (ii) State deference to internal } \\
\text { authority, in light of pluralism }\end{array}$ \\
\hline & & $\begin{array}{l}\text { (iii) Expect external adjudication } \\
\text { of secular actions in first instance }\end{array}$ & $\leftarrow$ & $\begin{array}{l}\text { (iii) State interference when } \\
\text { justified, esp. with secular }\end{array}$ \\
\hline
\end{tabular}

Figure 3.A mixed-purpose social action and a doctrine of organizational exemptions.

\section{(iii) Organizational Exemptions}

In this context, we encounter the secular yet religiously motivated activities of nonchurch organizations, such as for-profit firms. We also maintain the same moral norms as stated above. In this new context, however, we note a major difference in normative application, which lies in the external legal conditions posed given expected discrepancies in members' coordinating intentions-here, a lack of unanimity concerning religious belief and practice. This implies the ethically relevant circumstance of internal religious pluralism. ${ }^{117}$

With regard to for-profit firms, then, let us assume: (i) that members do not unanimously and directly intend to fulfil a distinctively religious end, ${ }^{118}$ (ii) that they do not consent to the group's authority procedures when the religious group act adversely affects them, and (iii) that they expect the group act (eg the sale of arts-andcrafts supply for the glory of God) to be subject in the first instance to external adjudication, particularly with regard to its secular elements, over which the state (it is assumed) has an appropriate degree of competency and jurisdiction. ${ }^{119}$

As for the external legal conditions that could support or limit this type of social action, they would be much the same as those found in a doctrine of freedom of the church. However, the fact of internal religious pluralism would make at least the second and third conditions more conditional. State deference to internal authorities would be especially mindful of vulnerable (and dissenting) group members, thus justifying certain occasions of state interference. I call this more attenuated collection of legal conditions a doctrine of organizational exemptions. ${ }^{120}$ Figure 3 provides an illustration, following the same pattern as Figure 2.

Considered together, the doctrines of freedom of the church and organizational exemptions constitute a natural law approach to corporate religious liberty. Differently put: they complete our procedure of corporate rights ascription, a

118 cf Michael A Helfand, 'What Is a “Church”?: Implied Consent and the Contraception Mandate' [2013] Pepperdine University School of Law, Legal Studies Research Paper Series 423 (arguing that employees give their implied consent to the religious aims of for-profit firms, especially when 'religious symbols ... or other concrete manifestations of a religious mission' are 'pervasive'). 
procedure informed by the natural law tradition, inclusive of its group ontology. And, to reiterate: the emphasis of this procedure is less about assigning legal rights to this or that group. Rather, it seeks to create conditions in which individuals can deliberate and coordinate for shared (religious) purposes in a morally appropriate way.

\section{A shift in Emphasis and Practical Benefits}

So what practical benefits does this procedure, with its emphasis upon external legal conditions, offer? Building upon our discussion in Section 3B, I draw attention to two benefits. These entail positive shifts in our approach to moral deliberation, as regards polarization and organizational scope.

Consider again rights-based polarization. Grounded in the concept of group right, the procedure above focuses upon right social action (in general and in two groupspecific contexts) instead of rights-holding in the first instance. Not only does this bridge the individual-group divide that is fostered by unrestrained rights-talk, ${ }^{121}$ but it also leaves open the specific form that proposed protections (or external legal conditions) could take.

For example, cognizant of religion's intrinsic value, a legal regime could emphasize a two-term rights relation, such as a general right to free religious exercise. This in turn could leave ambiguous the specific classes of subjects that would enjoy such a right. They would most likely be natural persons, but they could also be artificial corporate persons or groups understood as concrete rights-holding things. ${ }^{122}$ Alternatively, formally legal solutions could be de-emphasized (though not entirely eschewed), and individuals and groups could be free to establish internal, localized means to ensure that their religious actions are morally appropriate. For example, they themselves could initiate safeguarding protocols in religious schools in order to prevent and to report incidents of child sex abuse. ${ }^{123}$ Indeed, given the sensitivities of certain religious beliefs and practices (eg the sacrament of confession), a solution offered internally may be better than one imposed from outside. ${ }^{124}$

In these various cases, the appropriate means of protection or redress will be determined by the practical deliberation of individuals, whether private citizens or politicians. And assuming that individuals strive to avoid arbitrary reasons for their

See above Section 3B.

122 See above Section 3A.

123 For the principles and regulations that underlie the Catholic Church's own efforts in preventing child abuse, see USCCB, 'The Dallas Charter' (Creating a Safe Environment for All) <https://preventio nusccb.org/the-dallas-charter>; Pope Francis, 'Vos Estis Lux Mundi' (Vatican, 7 May 2019) <https:// w2.vatican.va/content/francesco/en/motu_proprio/documents/papa-francesco-motu-proprio20190507_vos-estis-lux-mundi.html> accessed 1 August 2019.

In May 2019, the state of California passed Senate Bill 360, which exempts clergy from divulging knowledge of abuse obtained from laity during a 'penitential communication'. However, with respect to knowledge gained from other clergy, there is a legal obligation to report. SB-360 Mandated reporters: clergy (2019) ss 2(d)(1)(A)-(E) and 2(d)(5)(A)-(B). Failure to comply results in 'up to six months of confinement in a county jail or ... a fine of one thousand dollars $(\$ 1,000)$ or ... both'. s 2(c). The logical flaws in, and behind, this state-crafted regulation are many. See, eg the analysis offered in Pius Pietrzyk, 'California Bill Targets Catholic Priests First, but Rights of All Religions Are at Risk' (USA Today, 29 April 2019) < https://eu.usatoday.com/story/opinion/voices/2019/04/28/california-religious-freedomcatholic-sex-abuse-column/3574921002/> accessed 1 August 2019. 
legal or policy deliberations, the seemingly de facto wielding of rights against rights could be less frequently deployed.

Does rights-talk ameliorate the tensions involved wedding-vendor cases, for instance? Or does it heighten emotions at the expense of finding reasonable common ground, that is, viable means of accommodating both gay rights and religious freedoms $?^{125}$ Often, it seems, the more public officials attempt to draw red lines with regard to specific rights-holders, the more polarized discussion becomes and, worse yet, the less progress is made towards reasonable solutions. ${ }^{126}$ There may be a virtue then in leaving a certain ambiguity in law, restraining from definitively specifying legal rights-holders, at least for a time. ${ }^{127}$ Then perhaps disagreeing parties of all sorts might be encouraged to come to shared terms of agreement themselves, thus fostering moral and civic virtues.

A related benefit deals with scope. The procedure offered above is organizationally inclusive yet morally discriminating about proposed legal conditions or solutions. This is achieved by a foundational and generic analysis of social action itself, which is then split into two group-specific forms of analysis. The rationale behind this division pertains, in part, to religion's distinct and intrinsic moral value. As a basic form of human good, religion deserves legal solicitude; by extension, individuals who coordinate around it - who form religious groups - also deserve legal solicitude. ${ }^{128}$

The division is further justified by the internal religious pluralism of non-church organizations. Since religion should not be coerced or forced upon others, organizations with mixed-purposes ought to be subject to a higher degree of state interference than churches or religious groups. Nevertheless, on the natural law approach articulated here, there is no principled ground for precluding non-church religious freedoms outright. Such ground could only be supplied by a substantively narrow set of normative principles. The concept of group right resists that restricted approach. Coupled with a substantively broad set of specific moral principles, it instead seeks to evaluate each action for its own particular merits, within its own particular circumstances.

Perhaps something of this logic is (rightly) taken up in the US Supreme Court's interpretation of the federal RFRA. Through it, writes Justice Kennedy, ' $\mathrm{t}]$ he Government must demonstrate that the application of a substantial burden to a person's exercise of religion " $(1)$ is in furtherance of a compelling governmental interest; and (2) is the least restrictive means of furthering that compelling governmental

For example, Masterpiece Cakeshop v Colorado Civil Rights Commission (2018) 138 SCt 1719 (Ginsburg, $\mathrm{J}$, and Sotomayor, J, dissenting) (holding that the 'Commission did not comply with the Free Exercise Clause's requirement of religious neutrality' in an anti-discrimination suit).

126 For example, Do No Harm Act 2017 HR 3222 (115th Cong) (enumerating a broad range of actiontypes, reducing the classes of persons able to be protected by the RFRA); similarly, The Equality Act 2017 HR 2282 (115th Cong) (adding 'sex, sexual orientation, and gender identity' as 'prohibited categories of discrimination or segregation in places of public accommodation' and, further, expanding the definition of public accommodations to include, eg 'gatherings' and 'programs'). For related and critical commentary, see Mark Movsesian, 'Masterpiece Cakeshop and the Future of Religious Freedom' (2019) 42 Harvard Journal of Law \& Public Policy 711.

127 Timothy Endicott, Vagueness in Law (Oxford University Press 2000) 2-7 (noting that vagueness is 'a very important source of law', allowing for judicial discretion). 
interest". 129 Far from having a 'startling breadth', ${ }^{130}$ such legislation seems reasonable: it allows religious exercise in its myriad corporate manifestations to be considered alongside, and not immediately subordinated to, other issues that bear strongly upon human well-being and the political common good. This openness seems an appropriate result of the natural law procedure outlined above.

\section{CONCLUSION}

In the conclusion to their chapter, 'Some Realism about Corporate Rights', Richard Schragger and Micah Schwartzman write that determining 'the moral and legal rights of groups can be conducted independently of arguments about metaphysics or ontology'. They continue:

We do not need to wait for a final answer on whether corporations are 'real', or 'mere aggregations', or fictional entities. Whatever the answer ultimately is, we will still be faced with all of the same issues concerning whether certain groups ought to have certain rights. We cannot escape those moral questions. But we can go a long way in answering them without asking (or answering) any metaphysical ones. ${ }^{131}$

I too share an emphasis upon the moral, but not at the expense of the metaphysical. As this article has argued, group ontology can be used in the assignment of corporate rights in a morally illuminating way. In particular, it is the ontology found within the classical natural law tradition that makes this possible.

Situated within moral philosophy itself, this ontology views groups primarily as social actions, which are subject to moral evaluation. It encourages movement away from combative rights-based moral analysis (with its immediate focus upon the corporate or individual rights-holder) and towards measured consideration of group right (that which is morally right in a given coordinative situation). This shift allows practical moral reasoning to discover a variety of (non-rights-based) reasons and means to protect or bring about the various goods pursued.

Thus, we see that group ontology on a natural law account is not morally distracting for corporate rights ascription. It offers a viable way of identifying the diverse moral stakes of corporate religious liberty disputes. And, when coupled with the (substantively broad) requirements of practical reason, the moral assessment it facilitates can be seen to exhibit greater care or discernment than the rights-based methods of the corporate-personality and voluntary-association paradigms discussed above.

By way of conclusion, it is worth highlighting a final practical effect of the above account of corporate religious liberty. As already noted, this account helps ameliorate rights-based polarization and organizational under- or over-inclusion. But we must also point out that it allows and even encourages a wide representation of individuals to engage in the process of moral deliberation itself. The significance of this latter 
effect cannot be overstated. Whereas the corporate personality paradigm concentrates power with corporate leaders (giving little to the state or individuals) and the voluntary association paradigm concentrates power with an individual rights- protecting state (thus exerting too much power over corporate bodies and, paradoxically, individuals), the paradigm implied by a natural law method seeks to spread that power more evenly so that public moral discourse is truly participatory and not weighed in favour of a few.

How does it do so? Ultimately through appeal to natural rights and a natural moral law, understood as adjudicating principles. Insofar as these principles implicate the metaphysical, then, pace Schragger and Schwartzman, recourse to them can in- 10 deed take us a long way. 


\section{Author Query Form}

Journal: Oxford Journal of Law and Religion

Article Doi: 10.1093/ojlr/rwz022

Article Title: Is Group Ontology Morally Distracting? A Natural

Law Approach to Corporate Religious Liberty

First Author: Edward A. David

Corr. Author: Edward A. David

\section{AUTHOR QUERIES - TO BE ANSWERED BY THE CORRESPONDING AUTHOR}

The following queries have arisen during the typesetting of your manuscript. Please click on each query number and respond by indicating the change required within the text of the article. If no change is needed please add a note saying "No change."

AQ1: $\quad$ Please check that all names have been spelled correctly and appear in the correct order. Please also check that all initials are present. Please check that the author surnames (family name) have been correctly identified by a pink background. If this is incorrect, please identify the full surname of the relevant authors. Occasionally, the distinction between surnames and forenames can be ambiguous, and this is to ensure that the authors' full surnames and forenames are tagged correctly, for accurate indexing online. Please also check all author affiliations.

AQ2: $\quad$ Please check if the suggested running head is okay.

AQ3: $\quad$ Please provide chapter name for the edited book.

AQ4: $\quad$ Please check if pinpoint mentioned in footnote 12 is correct.

AQ5: $\quad$ Please provide editor's name in footnotes 18,43 , and 85.

AQ6: Please check and confirm if 'emphasis in original' mentioned here is for this block quote 'power over others'.

AQ7: $\quad$ Please provide the full given names of authors in footnotes, unless initials are used in the original publications.

AQ8: $\quad$ Please provide year of publication in footnotes 40 and 123.

AQ9: $\quad$ Please check and confirm if 'emphasis in original' mentioned here is for 'must' in the block quote.

AQ10: Please provide last accessed date.

AQ11: In the sentence beginning 'Through it. .', as there is missing closing quote, we have inserted it. Please check and confirm. 
AQ12: Permission to reproduce any third party material in your paper should have been obtained prior to acceptance. If your paper contains figures or text that require permission to reproduce, please confirm that you have obtained all relevant permissions and that the correct permission text has been used as required by the copyright holders. Please contact jnls.author.support@oup.com if you have any questions regarding permissions. 